OPEN ACCESS

Edited by:

Ke Chen,

Woods Hole Oceanographic

Institution, United States

Reviewed by:

W. Judson Kenworthy, Independent Researcher, Beaufort,

United States

Gil Rilov,

Israel Oceanographic and Limnological Research, Israel

${ }^{*}$ Correspondence:

Russell C. Babcock russ.babcock@csiro.au

Specialty section: This article was submitted to Marine Ecosystem Ecology, a section of the journal

Frontiers in Marine Science

Received: 18 April 2019 Accepted: 03 July 2019 Published: 24 July 2019

Citation:

Babcock RC, Bustamante RH, Fulton EA, Fulton DJ, Haywood MDE, Hobday AJ, Kenyon R, Matear RJ,

Plagányi EE, Richardson AJ and

Vanderklift MA (2019) Severe Continental-Scale Impacts of Climate

Change Are Happening Now:

Extreme Climate Events Impact Marine Habitat Forming Communities

Along $45 \%$ of Australia's Coast.

Front. Mar. Sci. 6:411.

doi: 10.3389/fmars.2019.00411

\section{Severe Continental-Scale Impacts of Climate Change Are Happening Now: Extreme Climate Events Impact Marine Habitat Forming Communities Along $45 \%$ of Australia's Coast}

Russell C. Babcock ${ }^{1,2 *}$, Rodrigo H. Bustamante', Elizabeth A. Fulton ${ }^{3}$, Derek J. Fulton ${ }^{3}$, Michael D. E. Haywood ${ }^{1}$, Alistair James Hobday ${ }^{3}$, Robert Kenyon', Richard James Matear ${ }^{3}$, Eva E. Plagányi ${ }^{1}$, Anthony J. Richardson ${ }^{1,4}$ and Mathew A. Vanderklift ${ }^{5}$

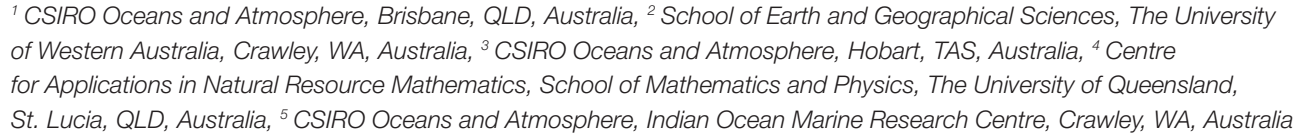

Recent increases in the frequency of extreme climate events (ECEs) such as heatwaves and floods have been attributed to climate change, and could have pronounced ecosystem and evolutionary impacts because they provide little opportunity for organisms to acclimate or adapt. Here we synthesize information on a series of ECEs in Australia from 2011 to 2017 that led to well-documented, abrupt, and extensive mortality of key marine habitat-forming organisms - corals, kelps, seagrasses, and mangroves - along $>45 \%$ of the continental coastline of Australia. Coral bleaching occurred across much of northern Australia due to marine heatwaves (MHWs) affecting different regions in 2011, 2013, 2016, and 2017, while seagrass was impacted by anomalously high rainfall events in 2011 on both east and west tropical coasts. A MHW off western Australia (WA) during the 2011 La Niña extended into temperate and subtropical regions, causing widespread mortality of kelp forests and seagrass communities at their northern distribution limits. Mangrove forests experienced high mortality during the 2016 El Niño across coastal areas of northern and north-WA due to severe water stress driven by drought and anomalously low mean sea levels. This series of ECEs reflects a variety of different events - MHWs, intense rainfall from tropical storms, and drought. Their repeated occurrence and wide extent are consistent with projections of increased frequency and intensity of ECEs and have broad implications elsewhere because similar trends are predicted globally. The unprecedented and widespread nature of these ECE impacts has likely produced substantial ecosystemwide repercussions. Predictions from ecosystem models suggest that the widespread mortality of habitat-forming taxa will have long-term and in some cases irreversible consequences, especially if they continue to become more frequent or severe. The 
abrupt ecological changes that are caused by ECEs could have greater long-term impacts than slower warming that leads to gradual reorganization and possible evolution and adaptation. ECEs are an emerging threat to marine ecosystems, and will require better seasonal prediction and mitigation strategies.

Keywords: extreme climate events, kelp, coral, seagrass, mangrove, marine heat wave, modeling, ecosystem

\section{INTRODUCTION}

Extreme climate events (ECEs), statistically rare or unusual climatic periods that alter ecosystem structure and/or function well outside normal variability (Smith, 2011), are receiving increasing attention as drivers of change in ecological and evolutionary communities (IPCC, 2012; van de Pol et al., 2017). ECEs are also associated with climate change, becoming more frequent and more intense (e.g., Herring et al., 2018). In coastal marine systems, heatwaves and floods could have greater ecosystem and evolutionary impacts than the more gradual effects of climate change (Campbell-Staton et al., 2017; Grant et al., 2017), and essentially represent a "pulse vs. press" dichotomy in terms of climate impact regime (Harris et al., 2018). For example, heatwaves compound the effects of underlying warming trends and provide little opportunity for organisms to acclimate or adapt, whereas slower warming is more likely to allow time for these processes to occur (Walther, 2010). Although there is a common perception that high-latitude areas will be most affected by climate change because the magnitude of warming is greater there (Burrows et al., 2011), lowlatitude areas with dampened seasonal cycles, have the greatest emergence of extreme heat (Diffenbaugh and Scherer, 2011) and host many species that inhabit environments already close to the limits of their thermal tolerance (Sunday et al., 2011, 2012; Frieler et al., 2013; Pinsky et al., 2019). Global warming is increasingly affecting marine ecosystems including habitat forming sessile organisms (Poloczanska et al., 2013), which are often key ecosystem engineers and particularly vulnerable to heatwaves as individuals cannot physically move to cooler locations (Mislan and Wethey, 2015).

Here we synthesize the unprecedented large-scale impacts of a series of ECEs on coastal marine habitats around the Australian continent (Figure 1) between 2011 and 2017, spanning both strong El Niño and La Niña phases of the El Nino Southern Oscillation (ENSO). We also model how impacts on habitat forming organisms propagate through food webs and ecosystems under a range of impact scenarios. The impact of ECEs throughout most of northern Australia has broad implications as the climate change phenomena driving the ECEs are being experienced globally (Oliver et al., 2018a). These conditions are also a precursor of a future in which ECEs are increasingly common, since ECEs are episodic, thus providing little or no time for acclimation and evolution, thus potentially exacerbating damage through the shocks they create within ecosystems (IPCC, 2012).

\section{ECE Impacts in Australia}

Vulnerability to marine extremes, such as heatwaves, has been demonstrated for many marine species (Poloczanska et al., 2013), but impacts to habitat-forming species may be most damaging. Around Australia and globally, coral reefs, kelp forests, mangroves, and seagrasses are all foundation species supporting diverse ecological communities (Steneck et al., 2002; Orth et al., 2006; Blaber, 2007; Nagelkerken et al., 2008; Waycott et al., 2009; Pratchett et al., 2011; Graham, 2014). Direct losses of significant portions of these habitats have been reported (e.g., McKenzie et al., 2014; Thomson et al., 2015; Wernberg et al., 2016a; Duke et al., 2017; Hughes et al., 2017), with predictions of wide-ranging effects that will significantly alter the communities associated with these ecosystems.

Half of Australian coastal waters have experienced their warmest ever monthly temperatures since 2008 (Figure 1), which reflects the increased extent, frequency and magnitude of marine heatwaves (MHWs; Hobday et al., 2016). The duration and magnitude of these events is also extending, with warmer sea temperatures persisting for longer than was recorded during previous extreme events (Hughes et al., 2017; Oliver et al., 2017). MHWs have increased around Australia and globally (Oliver et al., 2018a) and global climate models indicate that such MHWs are orders of magnitude more likely as a result of anthropogenic climate change (Oliver et al., 2017, 2018b). There is now a high level of consensus that, in addition to extreme warming events, climate change is also leading to extremes in other aspects of climate and weather, such as more severe storms (Herring et al., 2014, 2018; Stocker, 2014; Cheal et al., 2017). For example, extreme 1-day rainfall events estimated to occur once every 20 years in the 1950s are now expected to occur once every 15 years (Zhang et al., 2013; McInnes et al., 2015).

Extreme warming events have contributed to the abrupt, severe, and extensive impacts on key marine habitat-forming species including corals, kelp, seagrass, and mangroves along the Australian coastline in recent years. Below, for each key habitat forming biota, we briefly discuss their importance and their threats and then detail the recent ECEs in Australia and their impacts. We then use ecosystem models to estimate the overall impacts of ECEs of varying frequency on different ecosystems, and compare whether temperate or tropical environments are more likely to be impacted. We also discuss how understanding climate variability and change in marine ecosystems might be used to develop adaptation strategies to reduce potential impacts of ECEs.

\section{MATERIALS AND METHODS}

\section{Extreme Climate Impacts}

We reviewed the literature relating to impacts on Australia's coastal marine ecosystems of ECEs during the recent ENSO cycle, which spanned the La Niña of 2011 and the El Niño of 2016. 


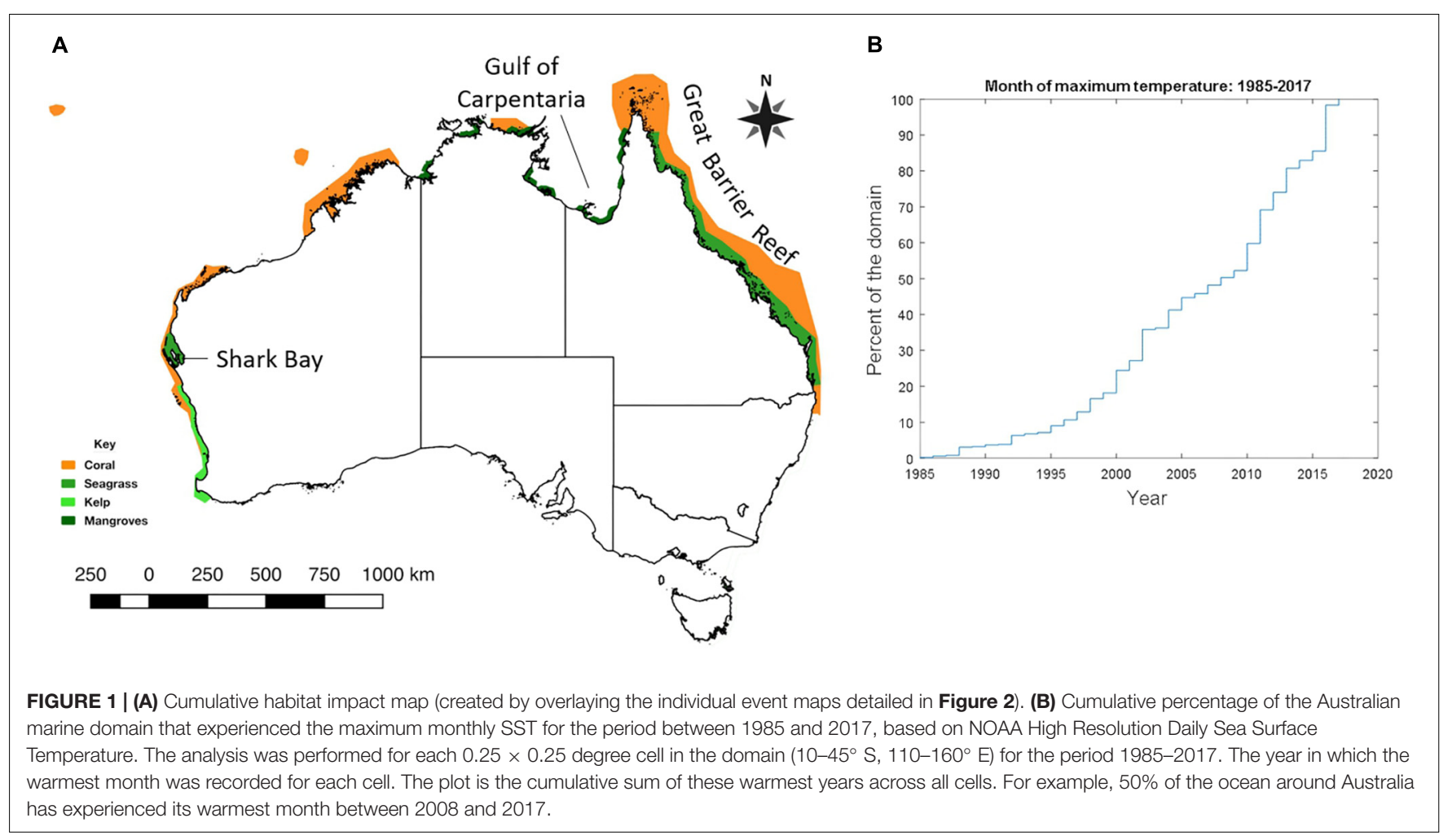

We examined the nature of the events as well as the extent and severity of impacts. This provided the basis for modeling of current and future ecosystem-wide impacts under a range of possible scenarios.

\section{Modeling Ecosystem-Wide Impacts}

The magnitude of habitat change caused by ECEs will have significant impacts on species dependent upon them and their associated food webs (Thomson et al., 2015; Wernberg et al., 2016a; Richardson et al., 2018). However, long-term implications are not yet clear because of short time series and the recent increase in such events. To address the potential long-term consequences, ecosystem models were used to explore ecosystem-wide impacts of ECEs and the sensitivity of these systems to differing disturbance patterns. There are ecosystem models for much of Australia's coastline and the models available for the areas affected by the ECEs (Table 1; with more detailed descriptions available in the Supplementary Materials) were used to explore the magnitude of potential trophic and habitat-mediated indirect effects. To account for uncertainty about the structure and linkages in the systems, a multi-model approach was taken. All systems had Ecopath with Ecosim (EwE) models (Christensen and Walters, 2004), and these were supplemented with Atlantis (Fulton et al., 2011) and InVitro (Fulton et al., 2011) models where available. The use of published EwE models across almost all systems provided a uniform basis for comparison across the various ecosystems, with the addition of the Atlantis and Invitro models providing insight into uncertainties regarding the level of potential change (or robustness) that result from uncertainty around the structure and dynamics of the ecosystems.

The Jurien Bay EwE model had the smallest spatial extent $\left(823 \mathrm{~km}^{2}\right)$ but the highest number of trophic groups (81), while at the other extreme the Great Barrier Reef (GBR) EwE model had the fewest trophic groups (31). The Atlantis-SE model for south-eastern Australia had the greatest spatial extent (at 3.7 million $\mathrm{km}^{2}$ ).

The use and dependency on habitats by reef and other species are explicit in Atlantis and InVitro. Mediation functions (where the state of the habitat influences the success of trophic interactions targeting the habitat dependent prey group) were used to capture the same dependency on biogenic habitats in the EwE models. Parameterizations of these dependencies were drawn from the same literature as the original model implementations or from the Atlantis and InVitro models of the same systems where available (Table 1).

An additional "ECE mortality" source was added to each model, and affected the main habitat forming primary producers, initially at low levels (causing biomass losses of only $3.4 \times 10^{-4}$ tonnes $\mathrm{km}^{-2} \mathrm{~d}^{-1}$ ), so that under standard conditions mortality is negligible. Major ECEs were then represented by forcing this mortality source to produce short-term mortalities with the same magnitudes of habitat decline as those reported in the literature discussed above. For instance, if corals suffered 50\% mortality due to severe bleaching in a particular region, then the mortality source was increased for simulated ECEs of 2 months duration, to a level that resulted in $50 \%$ realized mortality in the relevant model. In the currencies of the models the magnitudes of all trophic groups are represented in units of biomass and realized 
TABLE 1 | Details of the models used to investigate primary and indirect effects of extreme climate events.

\begin{tabular}{|c|c|c|c|c|c|}
\hline Region & Model type & $\begin{array}{l}\text { Number of functional } \\
\text { groups }\end{array}$ & Area $\left(\mathbf{k m}^{2}\right)$ & Notes & References \\
\hline Jurien Bay & EwE & 81 & 823 & & Lozano-Montes et al., 2011 \\
\hline Ningaloo & EwE, InVitro & 5243 & 28,700 & $\begin{array}{l}\text { Both models include fisheries, tourism, } \\
\text { agriculture, and oil and gas extraction. } \\
\text { InVitro also includes trucking, shipping, and } \\
\text { local urban areas; as well as forcing time } \\
\text { series for temperature, salinity, ocean } \\
\text { currents, and precipitation. }\end{array}$ & Fulton et al., 2011; Gray et al., 2013 \\
\hline North west Shelf & EwE & 37 & 70,000 & & Bulman, 2006 \\
\hline Kimberley & EwE & 58 & 93,000 & $\begin{array}{l}\text { In addition to commercial and recreational } \\
\text { fishing, the model contains: collection of } \\
\text { specimen shells, Trochus, marine aquarium } \\
\text { fish, pearl oyster and Beche-de-mer } \\
\text { mariculture, tourism, oil- and gas-related } \\
\text { stressors, shipping and coastal habitat } \\
\text { deterioration. }\end{array}$ & Boschetti et al., 2017 \\
\hline Gulf of Carpentaria & EwE & 53 & 396,483 & $\begin{array}{l}\text { Fisheries include indigenous collection, } \\
\text { charter vessels, and IUU activities. }\end{array}$ & $\begin{array}{l}\text { Bustamante et al., 2011; Dichmont } \\
\text { et al., } 2013\end{array}$ \\
\hline Great Barrier Reef & EwE & 32 & 325,848 & & Gribble, 2003 \\
\hline New South Wales Coast & EwE, Atlantis & 5754 & $48,00050,000$ & $\begin{array}{l}\text { Atlantis includes drivers for temperature, } \\
\text { salinity, ocean currents, and terrestrial } \\
\text { run-off. }\end{array}$ & Forrest et al., 2015 \\
\hline South East Australia & EwE, Atlantis & 5958 & $30,263 * 3,700,000$ & $\begin{array}{l}\text { Atlantis includes drivers for temperature, } \\
\text { salinity, ocean currents, and terrestrial } \\
\text { run-off. In addition to fisheries the model } \\
\text { contains aggregate mining, shipping, } \\
\text { marine energy sectors, and coastal } \\
\text { development. }\end{array}$ & Bulman et al., 2006; Fulton et al., 2014 \\
\hline Tasmania & EwE & 47 & 137,000 & Contains the potential for a pinniped cull. & Watson et al., 2013 \\
\hline
\end{tabular}

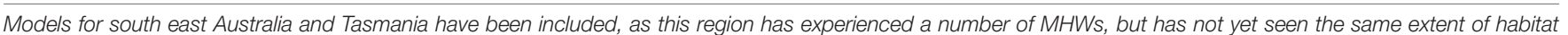
impact due to the decline of kelp in the area pre-dating the events (this does not, however, preclude further ECE-related change in the future). EwE, Ecopath with Ecosim.

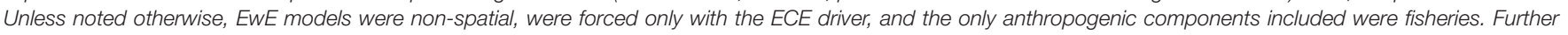

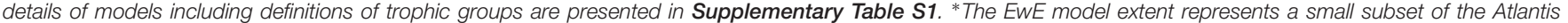
domain (around the eastern end of Bass Strait and the coast of Victoria).

mortalities are represented as reductions in total biomass of habitat formers. For the spatially explicit models, the footprint of the simulated ECE was set to match that of the real-world ECE in the same region.

To explore the full implications of extreme events for habitat formers and the stability of ecosystems dependent on them (Bender et al., 1984), three forms of extreme events scenario were considered with each model in which the frequency of ECEs was varied to assess the sensitivity of systems to disturbance frequency. We simulated a single major "pulse" event (with mortality rate returning to normal negligible levels after the ECE and remaining at those low levels for the rest of the 50 year run); "episodic" ECE-driven mortality events every 5 years; and a "step-change" such that the mortality-induced change in biomass becomes a permanent feature of the system. All of these are variations of "pulse" disturbances rather than a more gradual "press" impact of climate change. To provide first-order estimates of effects, these simulated ECEs were simplistic in that they did not account for synergies among different types of ECE, or the capacity of species to adapt to changing ECE frequency, duration, and intensity. The single exception to this is the Atlantis model for SE Australia. That model has the capacity to represent acclimation and evolution and simulations were run for that model, with and without that capacity enabled, to see what difference it made to the results. The effects of ECEs on the systems included assessment of the ability of the systems to recover to their original biomass and structure (Bender et al., 1984), and the speed at which this occurred.

\section{RESULTS AND DISCUSSION}

Australia has been impacted by an unprecedented number of ECEs since 2011, impacting $>45 \%$ of the coastline (Figure 2 ). We now describe in detail these impacts on the four major habitats around the coast.

\section{ECE Impacts Corals}

Coral reefs are home to $>83,000$ species (Fisher et al., 2015), more than any other marine ecosystem. The global economic value of coral reefs from both direct and indirect services is estimated to be in the billions to trillions of \$US per annum (Costanza et al., 2014; Spalding et al., 2017). Corals face a wide range of threats, including diminishing water quality, overfishing, and construction (Wilkinson, 2004). However, processes related 


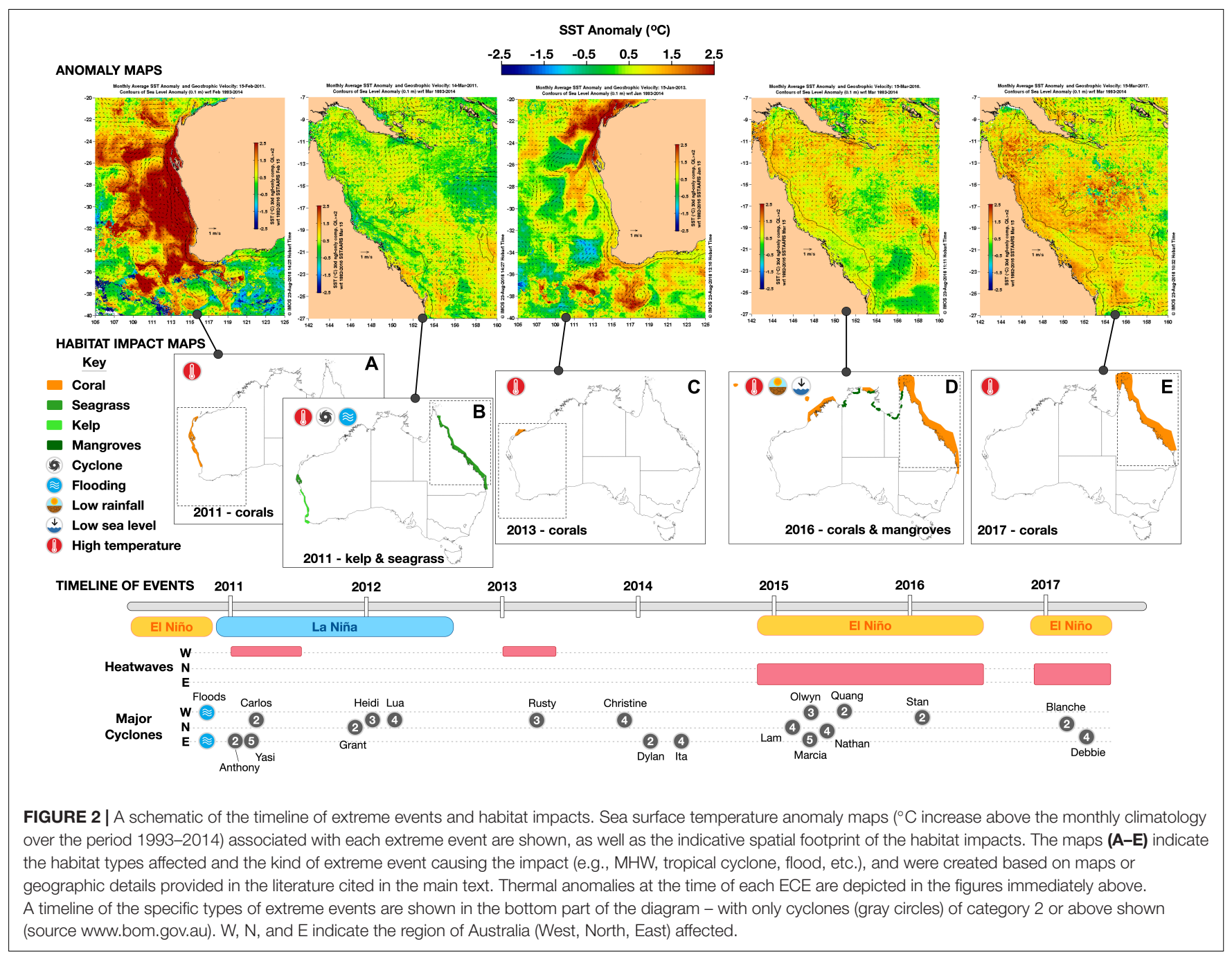

to climate change, in particular warming and ocean acidification, are increasingly threatening coral reefs (Heron et al., 2017). Bleaching of corals due to heat-induced breakdown in the relationship between corals and their symbiotic algae (Glynn et al., 2001; Smith et al., 2005) can lead to coral mortality, declines in total coral cover, changes in the composition of coral communities (Perry and Morgan, 2017b), subsequent reductions in reef calcification rates and physical structure (Perry and Morgan, 2017a), and drops in recruitment and recovery rates (Hughes et al., 2019). These changes in reef ecosystems will fundamentally change the nature of coral reefs (Stuart-Smith et al., 2018), with concomitant changes in the biodiversity and biomass of associated fish (Pratchett et al., 2011; Graham, 2014; Hughes et al., 2018; Richardson et al., 2018) and invertebrate (Przeslawski et al., 2008) communities. Coral reefs of Australia, including the world's largest reef, the GBR, are not immune to these threats, despite receiving a high level of legal protection (De'ath et al., 2012).

In the eastern Indian Ocean off Western Australia (WA) in 2011 there was an intense MHW, unprecedented in the 140-year local record (Wernberg et al., 2013). The 2010-2011 extreme La
Niña conditions in WA resulted in sea surface temperatures up to $5^{\circ} \mathrm{C}$ above normal (Figure 2). The MHW persisted for months along most of the west coast of Australia, resulting in widespread effects on corals. Bleaching and mortality were reported along a stretch of coast from Perth $\left(32^{\circ} \mathrm{S}\right)$ to the Exmouth Gulf $\left(21.75^{\circ}\right.$ S) (Abdo et al., 2012; Moore et al., 2012; Depczynski et al., 2013; Speed et al., 2013; Bridge et al., 2014). Effects of bleaching were most severe in parts of the northern extent (e.g., $>90 \%$ in Exmouth Gulf), with 19-50\% reduction at the Abrolhos Islands $\left(28.7^{\circ} \mathrm{S}\right)$ (Abdo et al., 2012; Bridge et al., 2014). Further south at Rottnest Island $\left(32^{\circ} \mathrm{S}\right)$, levels of bleaching and mortality were lower, around 17\% (Moore et al., 2012).

Heatwave conditions on the west coast abated in 2012, but anomalously warm waters returned in 2013 - this time to northwestern Australia $\left(21.75^{\circ}\right.$ to $\left.20.3^{\circ} \mathrm{S}\right)$, to the north of the region worst affected by the 2011 MHW. Bleaching and mortality of corals (Figure 2) were recorded on inshore (5168\%; Lafratta et al., 2017) and offshore reefs (69.3\%; Ridgway et al., 2016). The MHW was the result of La Niña conditions and the development of the "Ningaloo Niño" in the eastern Indian Ocean (Feng et al., 2013), which brings anomalously 
warm surface waters along the west coast of Australia (Zhang et al., 2017). Ningaloo Niño conditions were persistent during 2012 and 2013 (Feng et al., 2015), and have become increasingly frequent since the late 1990s. This is consistent with climate change projections (Cai et al., 2015).

By 2016, the ENSO index indicated an El Niño state with warm surface waters across much of the central western Pacific, and temperatures between Papua New Guinea and Australia were the warmest ever recorded (Oliver et al., 2018a; Figure 1B). Heating lasted much longer in 2016 than during previous bleaching episodes (e.g., 2002; Berkelmans et al., 2004), and more than twice as many reefs on the GBR experienced $>8$ Degree Heating Weeks (Hughes et al., 2017, 2018). Bleaching of corals in 2016 was the most severe and extensive so far recorded, with the most severe impacts seen in the northern GBR (Figure 2); there was severe bleaching ( $>60 \%$ of coral cover) and mortality recorded on most reefs between Torres Strait $\left(9.5^{\circ} \mathrm{S}\right)$ and Lizard Island $\left(15^{\circ} \mathrm{S}\right)$ and significant bleaching (30-60\%) on reefs as far south as $19^{\circ}$ S (Hughes et al., 2017). Bleaching and recovery were observed in corals further to the south, off the subtropical coast of eastern Australia (27.2-30 S; Hughes et al., 2017; Kennedy et al., 2018). Severe bleaching was also recorded at the same time along the northwestern coastline of the Northern Territory $\left(12^{\circ} \mathrm{S}, 134^{\circ} \mathrm{E}\right.$ to $16.45^{\circ} \mathrm{S}, 123.1 \mathrm{E}$ ), and on oceanic reefs between Australia and Indonesia (Scott Reef, $14^{\circ} \mathrm{S}, 121.8^{\circ} \mathrm{E}$; Christmas Island $10.5^{\circ} \mathrm{S}$, 105.6 ${ }^{\circ}$ E; Hughes et al., 2017).

In 2017, for the first time on record, there was a second consecutive year of bleaching on the GBR (Figure 2), extending south to $19^{\circ} \mathrm{S}$ (Great Barrier Reef Marine Park Authority, 2017; Hughes and Kerry, 2017). Approximately 50\% of the remaining corals were severely bleached, overlapping in spatial extent with bleached areas from 2016 but extending further south. The severity of these consecutive events, combined with the vulnerability of particular corals such as members of the genus Acropora to bleaching (Hughes et al., 2017), means that the composition of coral assemblages on reefs in the worst affected northern half of the GBR are unlikely to return to their former state in the foreseeable future (Hughes et al., 2018).

El Niño conditions that push a pool of warm-water toward the western Pacific and drive sea surface temperature anomalies on the GBR are projected to increase in frequency under climate change (Cai et al., 2014); long-term environmental proxy records already show a recent increase in ENSO variability in the central Pacific (Liu et al., 2017). Observations of coral bleaching in response to anomalously warm sea temperatures on the GBR extend back to 1998, with bleaching also recorded in 2002. Analysis of these records shows that reefs more frequently exposed to bleaching conditions in the past were more likely to bleach again (Hughes et al., 2017). Consequently, the likelihood of more frequent, more extensive, and increasingly severe bleaching of corals across the tropics of Australia appears to be increasing, as predicted, both for east and west coasts (Heron et al., 2017). Local weather features such as cyclones (Moore et al., 2012; Hughes et al., 2017) and upwelling (Xu et al., 2013) may lead to cooling that mediates bleaching effects in specific subregions; however, the location of such events will vary over time, reducing the likelihood of corals in any given area avoiding impact in the longer term. Further, the warm, oligotrophic waters of Australian coasts have localized and weak upwelling by global standards, which provides little abatement to the surface warming.

\section{Kelp Forests}

Kelp forests provide habitat for highly diverse assemblages of flora and fauna (Steneck et al., 2002) and make vital contributions to the productivity and economy of coastal habitats. For example, the estimated value of kelp forest habitats to the Australian economy is at least AU\$10 billion per year (Bennett et al., 2016). Kelp forests globally are facing threats from overfishing (Steneck et al., 2004), eutrophication (Coleman et al., 2008), and climate change (Wahl et al., 2015; Smale and Vance, 2016). Consequently, their loss has serious implications for the stability, productivity, and economic value of temperate coastal ecosystems. Declines in kelp forests lead to reductions in biodiversity (Airoldi et al., 2008; Ling, 2008), the biomass of fish and invertebrates such as abalone (Edgar et al., 2004), and recruitment of commercially important lobsters (Hinojosa et al., 2014; Hesse et al., 2016).

As a result of the WA MHW in 2011, abundance of the kelp Ecklonia radiata decreased by $>90 \%$ in the northern extent of its range, between 29 and $27.7^{\circ} \mathrm{S}$ (Figure 2), with local extinction of E. radiata on $370 \mathrm{~km}^{2}$ of reef during 2011 (Wernberg et al., 2016a). These warmer temperatures resulted in slower growth and impaired physiological performance of E. radiata adults and juveniles (Wernberg et al., 2010, 2016b; Bearham et al., 2013). More than $50 \%$ of Ecklonia stands were lost as far south as $30.5^{\circ}$ $\mathrm{S}$ and effects extended to south of $32.0^{\circ} \mathrm{S}$. Another large brown alga, Scytothalia doryocarpa, disappeared from $5 \%$ of its range, with a range contraction of $>100 \mathrm{~km}$ from 30.1 to $30.9^{\circ} \mathrm{S}$ and reductions in abundance as far as $31.9^{\circ} \mathrm{S}$ (Smale and Wernberg, 2013). The MHW in 2011 almost certainly caused the localized extinction of these two species of canopy-forming brown algae along $100 \mathrm{~km}$ of coast (Smale and Wernberg, 2013; Wernberg et al., 2016a). Since 2011, there has been no recovery of the kelp canopy in areas affected by the MHW, due to impaired recruitment and grazing by tropical herbivorous fish. It is thus likely that the shift in ecosystem structure throughout this region will persist for the foreseeable future even without further MHWs (Bennett et al., 2015; Wernberg et al., 2016a).

In contrast, kelp communities on the Australian east coast have undergone gradual declines in response to long-term warming (Supplementary Figure S1), providing insight into the contrasting mechanisms and impacts between gradual warming and ECEs. The east coast is experiencing long-term ocean warming due to more frequent and prolonged poleward penetration of the East Australian Current extension (Ridgway, 2007). At the Solitary Islands (29.7-30.1 ${ }^{\circ}$ S), 10 years of video evidence showed that the decline of $E$. radiata near its northern range limits, during a period in which SST warmed by $0.6^{\circ} \mathrm{C}$, was caused by increased abundance of herbivorous fish, which ate the kelp (Vergés et al., 2016). Similarly in Tasmania, the sea urchin Centrostephanus rodgersii has become established since the 1960s because water temperatures are now routinely warmer than the lower limits for larval survival (Ling, 2008). Sea urchins have now expanded along the Tasmanian coast $\left(39.6-43.4^{\circ} \mathrm{S}\right)$, facilitated by 
the rarity of large rock lobsters Jasus edwardsii, due to fishing, which are important urchin predators (Johnson et al., 2011). Sea urchins in turn have consumed much of the macroalgae in substantial areas of northern Tasmania, especially for canopyforming species E. radiata and Phyllospora comosa (Ling, 2008). While rapid on geological time scales, the gradual effects of warming temperatures in eastern Australian kelp forests over the past decades are more characteristic of changes in distribution commonly found in marine and terrestrial systems (Rosenzweig et al., 2008; Poloczanska et al., 2013) than are changes attributable to the WA MHW in 2011. Perhaps because kelp abundance was already reduced, the Tasman Sea MHW in 2016 apparently had little effect on remaining kelp forests of Tasmania (Oliver et al., 2017). In temperate Australia, as elsewhere, both gradual and extreme changes in temperature are shaping kelp ecosystems.

\section{Seagrasses}

Seagrasses form a critical component of many nearshore environments, helping to stabilize sediments and store carbon, providing food for megafauna such as turtles and dugong, and affording critical habitat for birds and recreationally and commercially important fish and invertebrates (Orth et al., 2006). Globally, the decline of seagrass meadows is accelerating (Waycott et al., 2009), attributed primarily to coastal development and deteriorating water quality (Waycott et al., 2009; Grech and Coles, 2010), although growing evidence suggests ECEs have also played a major role (Wetz and Yoskowictz, 2013). Cyclonic conditions can destroy seagrasses in shallow water through physical damage and smothering, while the associated heavy rainfall often results in turbid flood plumes that reduce available light for seagrasses (Longstaff and Dennison, 1999; Campbell and McKenzie, 2004; McKenzie et al., 2012). Elevated nutrient levels transported to the nearshore environment by floods can promote phytoplankton and epiphyte growth, further limiting the light and oxygen available to seagrasses (McKenzie et al., 2012).

During the 2010-2011 wet season along the north Queensland coast, combined impacts of a prolonged period of low salinity, light deprivation, and increased contaminant load (via terrestrial runoff) (Devlin et al., 2012) resulted in a major loss of seagrasses (Figure 2; Babcock et al., 2012; McKenzie et al., 2012, 2014; McKenna and Rasheed, 2013; Hanington et al., 2015). During this time, the formation of one of the strongest La Niñas (McKenna and Rasheed, 2013) brought a series of extreme events to the coast of north-eastern Australia (Hodgkinson et al., 2014). During this period, three tropical cyclones, including one category 5 , crossed the coast of tropical eastern Australia. This resulted in record river flows, with the total flow for all rivers adjacent to the GBR being 2.6 times the median flow. At their peak, flood plumes during this period covered 39\% of the GBR (Devlin et al., 2012). There were similar levels of flooding as far south as Moreton Bay, where an estimated sediment load $>1$ million tonnes (three times average annual load) was deposited into Moreton Bay over a 10-day period (DERM, 2011).

Severe declines in seagrasses were recorded in 2011 for regions within the GBR, with $>70 \%$ of all seagrass beds declining by $>20 \%$ and seagrass condition in all regions rated as "very poor" and at historically low levels (McKenzie et al., 2014). Similar, though less-extreme trends were reported in coastal areas south of the GBR, also associated with unusually high rainfall and flooding (Babcock et al., 2012). In February 2011, Tropical Cyclone Yasi (Category 5, Figure 2) not only brought high rainfall but also resulted in extensive physical damage to seagrasses within a $300-\mathrm{km}$ wide band across the continental shelf (Kennedy et al., 2018). Approximately 98\% of intertidal seagrass was lost in its path, and only a few isolated shoots remained in coastal and reef habitats (McKenzie et al., 2012). Following floods in 2011 in Queensland, there were record numbers of strandings of green turtles and high levels of strandings of dugongs that rely on seagrass for food (Meager and Limpus, 2014).

After the floods in early 2011, colonizing species of coastal seagrasses showed some recovery (e.g., $<10 \%$ of original cover) between Townsville and Moreton Bay during the ensuing 12 months (Babcock et al., 2012; McKenna and Rasheed, 2013; McKenzie et al., 2014), as did some deep-water seagrasses to the north of Townsville (McKenna and Rasheed, 2013). In contrast, there was no evidence of recovery in coastal inshore seagrasses by September 2012 (McKenna and Rasheed, 2013).

Seagrass meadows in Shark Bay on the west coast $\left(\sim 26^{\circ} \mathrm{S}\right)$ also experienced mortality during the $2011 \mathrm{MHW}$ (Thomson et al., 2015; Arias-Ortiz et al., 2018), possibly exacerbated by an extreme rainfall event in late December 2010 that led to prolonged (December 2010 to February 2011) flooding and high turbidity. Within the eastern embayment of Shark Bay, impacts of the heatwave and the flooding potentially acted synergistically on the seagrass damaging $36 \%$ of the seagrass community, causing $22 \%$ loss of extent and exposing organic carbon in sediments to oxic conditions (Arias-Ortiz et al., 2018). Amphibolis antarctica is close to its northern limit of distribution at Shark Bay, suggesting it could be sensitive to increases in temperature (Walker and Cambridge, 1995) or deterioration in conditions. Similar to the east coast, turtle health was affected in Shark Bay following declines in seagrass cover (Thomson et al., 2015). The slow growth rate of $A$. antarctica and observations that below-ground biomass continued to decline for several years following the MHW (Fraser et al., 2014; Thomson et al., 2015) suggest future recovery will be slow. These events are an example of how different types of ECEs that are linked to larger-scale variability in climate such as ENSO (e.g., Figure 2) can be clustered in time, and thus compromise the natural coping mechanisms of many species.

\section{Mangroves}

Remote tropical Australian coasts support undisturbed mangrove forests and adjacent estuarine and shallow coastal waters of global significance (Halpern et al., 2008). Mangrove forests are responsible for major components of the primary productivity of coastal habitats that support fish and fisheries, both globally and in northern Australia (Blaber, 2007). The physical structure of mangrove forests provides both shelter and a stable substrate for flora and fauna, as well as increasing soil stability on which subterranean communities of fish, crustaceans, and detritus recyclers rely (Nagelkerken et al., 2008). 
During the summer of 2015-2016, a significant area (7400 ha) of mangroves in the Gulf of Carpentaria (GOC) died (Figure 2), mostly in tracts along the coastline from the western GOC to the south-east GOC (Duke et al., 2017; Harris et al., 2018). The scale of this dieback, over $1000 \mathrm{~km}$ in linear extent of saltflat- and beach-backed coasts, was far more extensive than any reports of previous diebacks (e.g., Paling et al., 2008). The dieback affected $6 \%$ of the overall GOC mangrove community, and in some

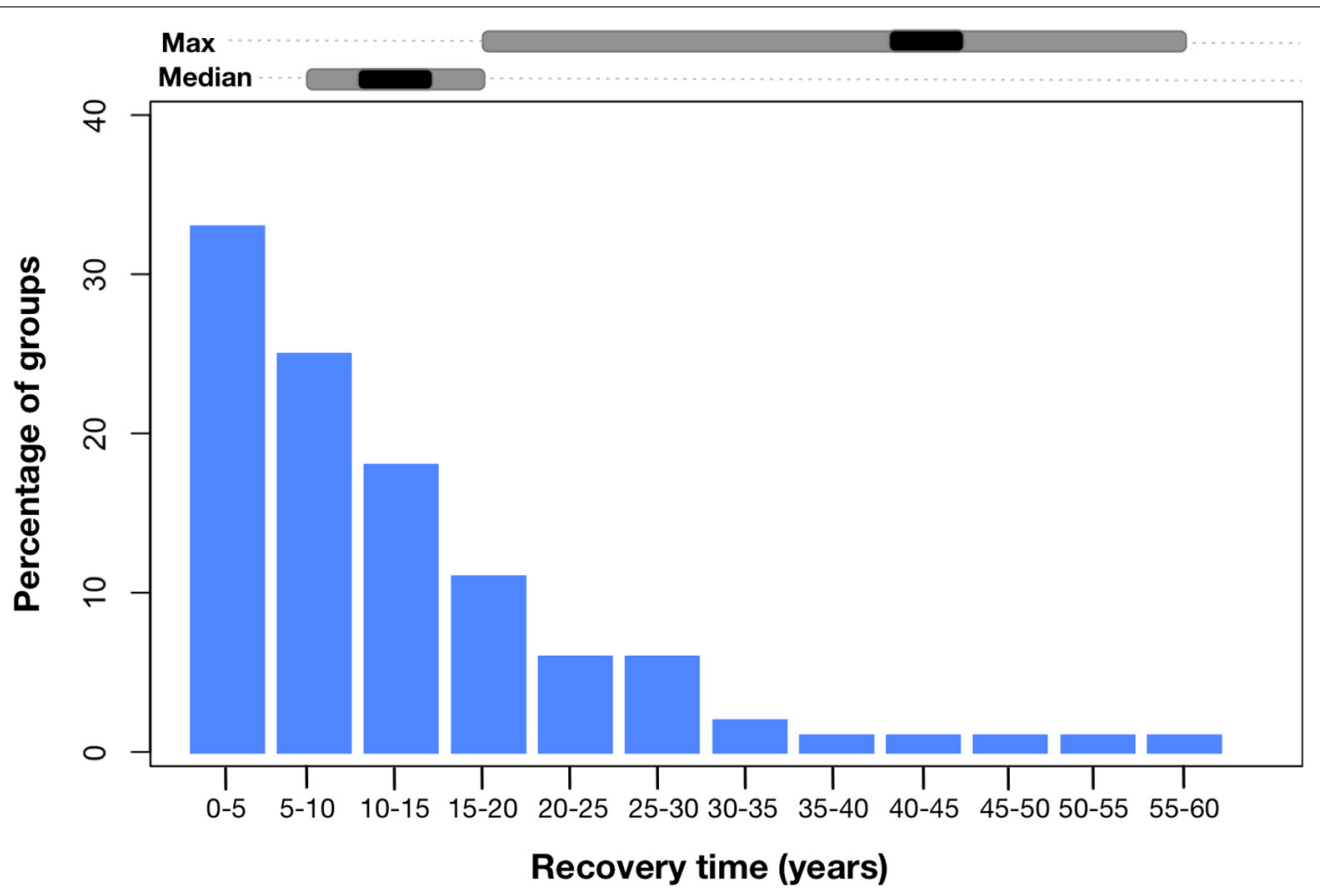

FIGURE 3 | Distribution of recovery times (across all groups in all models). The spread of the median and maximum ranges of recovery times at a system level are shown in gray bars above the plot, with the median across systems shown in black.
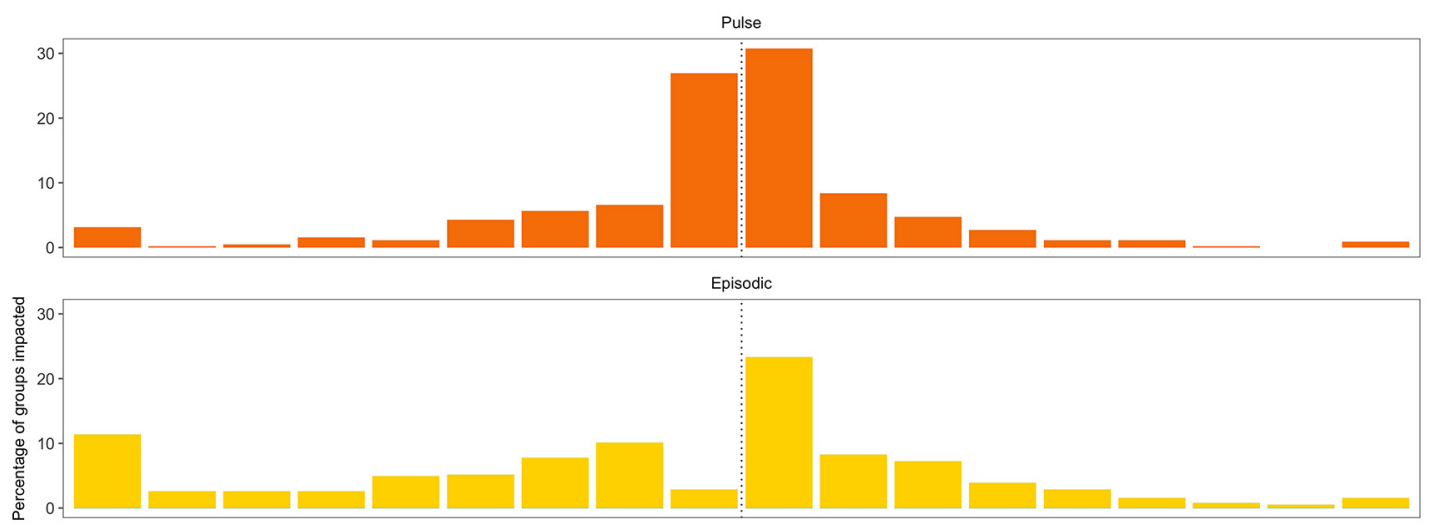

Frequency of extreme events

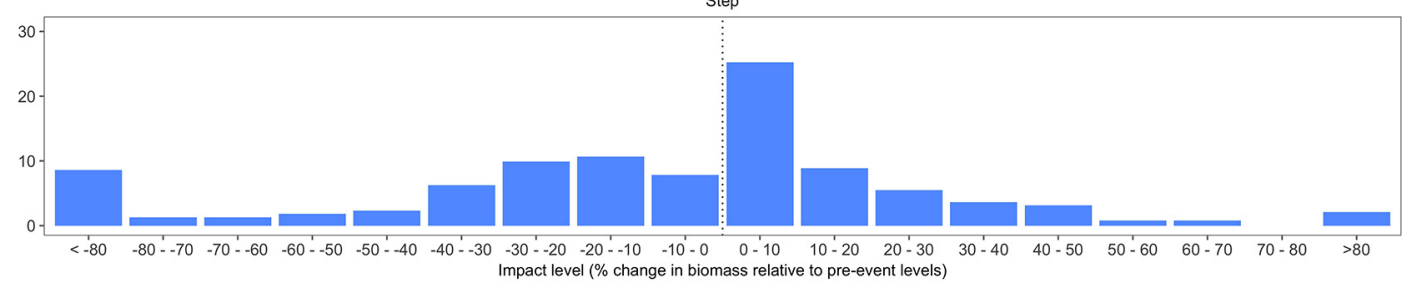

FIGURE 4 | Ecosystem impact plots showing the distribution of percentage change in relative biomass (in comparison to pre-event levels) under the three scenarios: pulsed, episodic, or step-change in the frequency of extreme events (plots aggregate results across all groups in all models). 
regions dieback affected up to $26 \%$ of the mangrove stands. At locations in the eastern GOC $\left(\sim 17.5^{\circ} \mathrm{S}, 140.9^{\circ} \mathrm{E}\right)$, the coastal Avicennia marina community suffered complete mortality. In other locations, such as in the western GOC $\left(15^{\circ} \mathrm{S}, 138.7^{\circ} \mathrm{E}\right)$, two species of mangrove died (A. marina and Rhizophora stylosa), each along the landward edge of the upper tidal limit of their distribution, despite the two species inhabiting different tidal levels. Mortality of mangroves was also reported in early 2016 as far away as the Northern Territory $\left(12.2^{\circ} \mathrm{S}, 132.7^{\circ} \mathrm{E}\right.$; Lucas et al. 2017) and the Australian west coast $\left(22.0^{\circ} \mathrm{S}\right)$ and was due to ENSO-linked sea level changes (Lovelock et al., 2017) that affect the whole northern Australian region, suggesting that there may have been further diebacks in remote areas that were unreported.

By late 2015, affected areas of the GOC had experienced lower-than-average rainfall for the previous 3 years, record hot temperatures in the preceding 6 months, and abnormally low sea-level (>20 cm below mean sea level) (Duke et al., 2017). This was coincident with a strong El Niño, resulting in ECE conditions across northern Australia. Mangrove forests require freshwater for survival and, though they use saltwater as well, many mangroves live close to their salinity tolerance levels (Parida and Jha, 2010). It is likely that mangrove tracts suffered from a combination of soil moisture stress, loss of monthly inundation of the upper intertidal on neap tides, and abnormally hot temperatures over an extended period. The recent mangrove diebacks in northern Australia took place within otherwise pristine mangrove ecosystems, few of which remain worldwide, and illustrate impacts on tropical stands suffering dieback from soil moisture stress (see Duke et al., 2017; Lovelock et al., 2017).

\section{Modeling ECE Impacts}

Results from the ecosystem models of simulations of extreme event scenarios indicate that there are clear and potentially substantial effects of ECEs (Figure 3). After a single extreme event, recovery times for individual functional groups ranged from 4 to 60 years. While median recovery time was more typically 10-15 years, a long tail of continuing small-scale effects was evident (Figure 3), with biomass of primarily slower-growing or longer-lived groups departing from pre-event levels for decades.

Since median recovery time is estimated to be $10-15$ years (Figure 3), and the frequency of ENSO-related ECEs is projected to be 1 in 15 years (Cai et al., 2014), coastal ecosystems are unlikely to recover fully between ECEs, resulting in compounding effects on ecosystem structure and function. For example, if events were once-off or relatively infrequent, longer-term shifts were small for the majority of groups $(<5 \%)$, however, as frequency increased so did the mean size of the impact on biomass each functional group - increasing to be $8-10 \%$ for most groups (Figure 4). This mean hides considerable variation, with biomass of habitat-forming groups and species dependent upon them - particularly large-bodied reef or meadow-dependent species - declining substantially (e.g., by $>80 \%$ ), while other generalist or more opportunistic species increase in abundance (e.g., small herbivorous fish in Jurien Bay, WA, increase by $48 \%$; fish species characteristic of degraded and disturbed habitats increasing in tropical models and demersal omnivores and invertebrate feeders increasing in temperate models). For fisheries, these shifts in biomass had substantial negative effects on landed catches, which were predicted to fall by $15-25 \%$ overall.

Across the different types of models, those capturing the time delays inherent in habitat recovery (Atlantis, InVitro, and EwE models with stanza representations of corals) predicted the longest recovery times. Maximum recovery times ranged from 15-20 to 55-60 years, with median values between 40 and 45 years (Figure 3). Moreover, tropical systems took longer to recover than temperate systems and showed a greater propensity for the consequences of individual ECE to last decades. Allowing for acclimation and evolution in the Atlantis model of south east Australia lessened the effect of ECEs, halving the magnitude of biomass declines and shortening recovery times by $\sim 40 \%$, but did not negate all impacts.

\section{CONCLUSION}

Widespread and severe impacts of climate change are not simply a problem we might face in the future, they are happening now. We have detailed recent severe, abrupt, and widespread impacts of climate change related to environmental extremes affecting globally significant habitat-forming corals, seagrasses, kelps, and mangroves around Australia. Since 2011, $>45 \%$ of the coastline of the Australian continent has been affected by ECEs, which are unprecedented in intensity, and are becoming more frequent, such as the multiple bleaching episodes of coral reefs in WA and on the GBR. This manifestation of climate change - an increase in episodic ECEs - differs from a more gradual model of climate change driven solely by changes in mean temperature assumed in most modeling of future biodiversity distribution (e.g., Burrows et al., 2014; Lenoir and Svenning, 2015). Marine life is more likely to be able to adapt to the gradual climate change in coastal marine ecosystems that is occurring in Australia (e.g., in kelp forests of southeastern Australia; Ling, 2008; Vergés et al., 2016) and globally (Bates et al., 2018), than to the abrupt ECEs that we describe here.

When effects of gradual climate-related change in coastal habitats around southeastern Australia are added to ECE impacts (Supplementary Figure S1), the proportion of coastline affected around Australia reaches almost 50\%. Regardless of the mechanisms, the public reaction to these vast impacts has been relatively muted, particularly relative to the concern that results from localized accidents such as oil spills, shipwrecks, or coastal developments. For example, the Deepwater Horizon accident in the Gulf of Mexico caused a global outcry far larger than for any of the events documented here, yet it affected at most $2100 \mathrm{~km}$ of coast (Beyer et al., 2016) with apparently short-lived impacts so far (Lin and Mendelssohn, 2012). In contrast the length of coastline affected by the ECEs in the last decade described here is around $8000 \mathrm{~km}$, nearly four times greater in extent and includes impacts that appear likely to be irreversible at least on decadal scales and possibly longer (Wernberg et al., 2016a; Hughes et al., 2018). Recent 
modeling strongly suggests that the reduction in extent of key habitats such as kelp forest will continue to change rapidly with a reduction in extent of kelp forests of up to $70 \%$ by 2100 (Martínez et al., 2018).

Climate change is exacerbating ECEs on land (Christidis et al., 2015; Mann et al., 2017; Harris et al., 2018), including recent hurricanes in the Caribbean and the United States, and in the ocean (e.g., Wetz and Yoskowictz, 2013; Brown et al., 2016; Oliver et al., 2018a). In the future, atmospheric (Fischer et al., 2013) and marine (Oliver et al., 2017) heatwaves are expected to increase in frequency and duration under climate change. The Coupled Model Intercomparison Project (CMIP5) models project terrestrial heatwaves to become more frequent, hotter, and last longer across Australia by the end of the 21st century (Cowan et al., 2014). Projections for northern Australia show the largest increase in heatwave days, due to the narrow temperature distribution in the tropics (e.g., Diffenbaugh and Scherer, 2011). Given that global climate models project significant increases in extreme El Niño and La Niña events (Cai et al., 2014, 2015) and a continuation of positive Southern Annual Mode trends in the Representative Concentration Pathways (RCP8.5) scenario (Zhang et al., 2013), there is likely to be an increase in MHWs and ECEs in Australia (and globally), with impacts felt more acutely in northern Australia (Oliver et al., 2018b). Tropical storms (Walsh et al., 2016) are likely to become more intense, and rainfall events and sea levels (Zhang et al., 2013; Widlansky et al., 2015) will also become more extreme and more likely. The scale of the ECE impacts observed around the Australian coastline is also an issue of concern, since sessile species rely on recruits (whether larvae, spores, or seeds) from outside the impacted area for recovery, with likely implications for the resilience of affected systems (e.g., Hughes et al., 2017).

Based on our literature synthesis and modeling, ECE impacts to ecosystems are likely to become more severe and extensive in the relatively near future. Indeed, they are happening now, and based on this Australian analysis, may be more common globally than currently appreciated, and have longer lasting impacts in the tropics than in temperate regions. ECE impacts on kelp in south WA are consistent with this hypothesis, since seasonal temperature extremes in this region are moderated by the poleward-flowing Leeuwin current, which is strongest during winter (Rochford, 1984). Widespread ECE impacts are not restricted to the Australian coast but are widespread globally (Smale et al., 2019). These events are changing ecosystems in profound ways that in some cases are unlikely to be reversible. ECE impacts also suggest that while climate change may be viewed as gradual, in many cases it manifests through a series of often extreme and abrupt changes. It is significant that impacts of climate change may manifest through ECEs because heatwaves provide little opportunity for acclimation or adaptation, in contrast to more gradual warming (Walther, 2010) such as on Australia's temperate east coast. Whereas studies of mobile species suggest that ECEs may lead to rapid evolution because of the dramatic selective pressures they impose (van de Pol et al., 2017), the implication for habitat-forming sessile marine species may be quite different and more serious as they can be particularly vulnerable to heatwaves. Sessile organisms lack the ability to physically move to cooler locations (Mislan and Wethey, 2015) except by establishing new populations via larval transport; therefore, for marine species in particular the velocity of climate change may exceed the ability of most species' populations to extend their range (Burrows et al., 2011). Further, it is uncertain whether immigrant species arriving in new latitudes would actually be able to adapt (Sommer et al., 2018). In addition, disrupted ecosystems that have been stable for millennia have non-biological consequences, such as the release of carbon from stable sediment accumulation (Arias-Ortiz et al., 2018). As such, ECEs will have significant consequences not only for coastal marine ecosystems but also for the human economic, social, and political systems that depend on them.

The results of modeling ECE impacts on coastal habitats around Australia provide insights into a range of potential futures for marine ecosystems around the continent, some of which may have serious ecological and social implications. As such they provide a useful assessment of the risks faced in the future but also hypotheses that must be evaluated by targeted observations if we are to refine our understanding of climate and ECE impacts. Such refinements are essential if we are to make practical steps to minimize or manage these impacts, particularly since combined press (incremental global warming) and pulse (ECE) disturbances may produce unpredictable interactions and outcomes (Underwood, 1989).

Extreme climate events can act as a catalyst for transformational adaptation to climate change (Travis, 2014). We need to combine our efforts to forecast the climate on seasonal to multi-year timescales with our understanding of marine ecosystem responses at both species and ecosystem level to develop and test strategies to minimize impacts of ECEs. In developing adaptation strategies, we need to consider that ECEs can trigger fundamental shifts in ecosystems (van de Pol et al., 2017), and that the loss of resilience often precedes ecosystem shifts (Scheffer et al., 2001). Therefore, adaptive management strategies that maintain ecosystem resilience continue to be important. Adaptation strategies also need to be flexible and adaptive in response to the information revealed by monitoring and assessment (Schindler and Hilborn, 2015). It is also likely that such strategies must include active restoration approaches (Anthony et al., 2017). This requires close integration between management interventions with ecosystem research.

\section{DATA AVAILABILITY}

The datasets generated for this study are available on request to the corresponding author.

\section{AUTHOR CONTRIBUTIONS}

$\mathrm{RCB}, \mathrm{RHB}, \mathrm{EF}, \mathrm{MH}, \mathrm{AR}$, and MV conceived the manuscript. RCB, RHB, EF, DF, MH, AH, RK, RM, EP, AR, and MV wrote the manuscript. EF performed the ecosystem modeling. DF, $\mathrm{MH}$, and $\mathrm{AH}$ conceived and executed the figures. 


\section{FUNDING}

This project was funded in part by the Gorgon Barrow Island Net Conservation Benefits Fund, which is administered by the Western Australian Department of Parks and Wildlife and by the CSIRO Oceans and Atmosphere.

\section{ACKNOWLEDGMENTS}

We would like to thank the many leading researchers, students, and members of the public for publishing and documenting the unprecedented impacts of extreme events and climate change

\section{REFERENCES}

Abdo, D. A., Bellchambers, L. M., and Evans, S. N. (2012). Turning up the heat: increasing temperature and coral bleaching at the high latitude coral reefs of the Houtman Abrolhos Islands. PLoS One 7:e43878. doi: 10.1371/journal.pone. 0043878

Airoldi, L., Balata, D., and Beck, M. W. (2008). The gray zone: relationships between habitat loss and marine diversity and their applications in conservation. J. Exp. Mar. Biol. Ecol. 366, 8-15. doi: 10.1016/j.jembe.2008.07. 034

Anthony, K., Bay, L. K., Costanza, R., Firn, J., Gunn, J., Harrison, P., et al. (2017). New interventions are needed to save coral reefs. Nat. Ecol. Evol. 1, 1420-1422.

Arias-Ortiz, A., Serrano, O., Masqué, P., Lavery, P. S., Mueller, U., Kendrick, G. A., et al. (2018). A marine heatwave drives massive losses from the world's largest seagrass carbon stocks. Nat. Clim. Change 8, 338-344. doi: 10.1038/s41558018-0096-y

Babcock, R., Haywood, M., Clark, T., Cheers, S., Dell, Q., and Holmes, M. (2012). Seagrass Response to the 2011 Floods in Southeast Queensland. Brisbane: CSIRO Marine and Atmospheric Research.

Bates, A. E., Helmuth, B., Burrows, M. T., Duncan, M. I., Garrabou, J., Guy-Haim, T., et al. (2018). Biologists ignore ocean weather at their peril. Nature 560, 299-301. doi: 10.1038/d41586-018-05869-5

Bearham, D., Vanderklift, M. A., and Gunson, J. R. (2013). Temperature and light explain spatial variation in growth and productivity of the kelp Ecklonia radiata. Mar. Ecol. Prog. Ser. 476, 59-70. doi: 10.3354/meps10148

Bender, E. A., Case, T. J., and Gilpin, M. E. (1984). Perturbation experiments in community ecology: theory and practice. Ecology 65, 1-13. doi: 10.2307/ 1939452

Bennett, S., Wernberg, T., Connell, S. D., Hobday, A. J., Johnson, C. R., and Poloczanska, E. S. (2016). The 'Great Southern Reef': social, ecological and economic value of Australia’s neglected kelp forests. Mar. Freshw. Res. 67, 47-56. doi: 10.1071/MF15232

Bennett, S., Wernberg, T., Harvey, E. S., Santana-Garcon, J., and Saunders, B. (2015). Tropical herbivores provide resilience to a climate mediated phase-shift on temperate reefs. Ecol. Lett. 18, 714-723. doi: 10.1111/ele.12450

Berkelmans, R., De'ath, G., Kininmonth, S., and Skirving, W. J. (2004). A comparison of the 1998 and 2002 coral bleaching events on the Great Barrier Reef: spatial correlation, patterns, and predictions. Coral Reefs 23, 74-83. doi: 10.1007/s00338-003-0353-y

Beyer, J., Trannum, H. C., Bakke, T., Hodson, P. V., and Collier, T. K. (2016). Environmental effects of the deepwater horizon oil spill: a review. Mar. Pollut. Bull. 110, 28-51. doi: 10.1016/j.marpolbul.2016. 06.027

Blaber, S. J. (2007). Mangroves and fishes: issues of diversity, dependence, and dogma. Bull. Mar. Sci. 80, 457-472.

Boschetti, F., Lozano-Montes, H., Stelfox, B., Bulman, C., Strzelecki, J., and Hughes, M. (2017). Knowledge Integration and MSE Modelling. Final Report of Project 2.2.8. Perth, WA: Western Australian Marine Science Institution, 47.

Bridge, T. C., Ferrari, R., Bryson, M., Hovey, R., Figueira, W. F., Williams, S. B., et al. (2014). Variable responses of benthic communities to anomalously warm affecting the coastal and marine ecosystems of Australia. Without their valuable contributions this work would have not been possible. We would also like to thank Dr. Andy Steven for supporting this work. We acknowledge the insights and inputs of Dr. John Parslow and very numerous reviewers for their comments on the manuscript.

\section{SUPPLEMENTARY MATERIAL}

The Supplementary Material for this article can be found online at: https://www.frontiersin.org/articles/10.3389/fmars. 2019.00411/full\#supplementary-material

sea temperatures on a high-latitude coral reef. PLoS One 9:e113079. doi: 10. 1371/journal.pone.0113079

Brown, C. J., O’Connor, M. I., Poloczanska, E. S., Schoeman, D. S., Buckley, L. B., Burrows, M. T., et al. (2016). Ecological and methodological drivers of species' distribution and phenology responses to climate change. Glob. Change Biol. 22, 1548-1560. doi: 10.1111/gcb.13184

Bulman, C. (2006). Trophic Webs and Modelling of Australia's North West Shelf. CSIRO North West Shelf Joint Environmental Management Study Technical Report No 9. Hobart: CSIRO, 85.

Bulman, C., Condie, S., Furlani, D., Cahill, M., Klaer, N., Goldsworthy, S., et al. (2006). Trophic Dynamics of the Eastern Shelf and Slope of the South East Fishery: Impacts of and on the Fishery. CSIRO Final Report for Fisheries Research \& Development Corporation Project No. 2002/028. Hobart, TAS: CSIRO, 197.

Burrows, M. T., Schoeman, D. S., Buckley, L. B., Moore, P., Poloczanska, E. S., and Brander, K. J. (2011). The pace of shifting climate in marine and terrestrial ecosystems. Science 334, 652-655. doi: 10.1126/science.1210288

Burrows, M. T., Schoeman, D. S., Richardson, A. J., Molinos, J. G., Hoffmann, A., Buckley, L. B., et al. (2014). Geographical limits to species-range shifts are suggested by climate velocity. Nature 507, 492-495. doi: 10.1038/nature12976

Bustamante, R. H., Dichmont, C. M., Ellis, N., Griffiths, S., Rochester, W. A., Burford, M. A., et al. (2011). Effects of Trawling on the Benthos and Biodiversity: Development and Delivery of a Spatially-Explicit Management Framework for the Northern Prawn Fishery. Final report to the Project FRDC 2005/050. Cleveland, OH: CSIRO Marine and Atmospheric Research, 382.

Cai, W., Borlace, S., Lengaigne, M., Van Rensch, P., Collins, M., Vecchi, G., et al. (2014). Increasing frequency of extreme El Niño events due to greenhouse warming. Nat. Clim. Change 4, 111-116. doi: 10.1038/nclimate2100

Cai, W., Wang, G., Santoso, A., McPhaden, M. J., Wu, L., Jin, F. F., et al. (2015). Increased frequency of extreme La Niña events under greenhouse warming. Nat. Clim. Change 5, 132-137.

Campbell, S. J., and McKenzie, L. J. (2004). Flood related loss and recovery of intertidal seagrass meadows in southern Queensland, Australia. Estuar. Coast. Shelf Sci. 60, 477-490. doi: 10.1016/j.ecss.2004.02.007

Campbell-Staton, S. C., Cheviron, Z. A., Rochette, N., Catchen, J., Losos, J. B., and Edwards, S. V. (2017). Winter storms drive rapid phenotypic, regulatory, and genomic shifts in the green anole lizard. Science 357, 495-498. doi: 10.1126/ science.aam 5512

Cheal, A. J., Macneil, M. A., Emslie, M. J., and Sweatman, H. (2017). The threat to coral reefs from more intense cyclones under climate change. Glob. Change Biol. 23, 1511-1524. doi: 10.1111/gcb.13593

Christensen, V., and Walters, C. J. (2004). Ecopath with Ecosim: methods, capabilities and limitations. Ecol. Modell. 172, 109-139. doi: 10.1016/j. ecolmodel.2003.09.003

Christidis, N., Jones, G. S., and Stott, P. A. (2015). Dramatically increasing chance of extremely hot summers since the 2003 European heatwave. Nat. Clim. Change 5, 46-50. doi: 10.1038/nclimate2468

Coleman, M. A., Kelaher, B. P., Steinberg, P. D., and Millar, A. J. (2008). Absence of a large brown macroalga on urbanized rocky reefs around Sydney, Australia, and evidence for historical decline. J. Phycol. 44, 897-901. doi: 10.1111/j.15298817.2008.00541.x 
Costanza, R., de Groot, R., Sutton, P., van der Ploeg, S., Anderson, S. J., Kubiszewski, I., et al. (2014). Changes in the global value of ecosystem services. Glob. Environ. Change 26, 152-158.

Cowan, T., Purich, A., Perkins, S., Pezza, A., Boschat, G., and Sadler, K. (2014). More frequent, longer, and hotter heat waves for Australia in the twenty-first century. J. Clim. 27, 5851-5871. doi: 10.1175/jcli-d-14-00092.1

De'ath, G., Fabricius, K. E., Sweatman, H., and Puotinen, M. (2012). The 27-year decline of coral cover on the Great Barrier Reef and its causes. Proc. Natl. Acad. Sci. U.S.A. 109, 17995-17999. doi: 10.1073/pnas.1208909109

Depczynski, M., Gilmour, J. P., Ridgway, T., Barnes, H., Heyward, A. J., Holmes, T. H., et al. (2013). Bleaching, coral mortality and subsequent survivorship on a West Australian fringing reef. Coral Reefs 32, 233-238. doi: 10.1007/s00338012-0974-0

DERM (2011). South East Queensland Event Monitoring Summary (6th-16th January 2011): Preliminary Suspended Solids Loads Calculations, Healthy Waterways. Brisbane: Queensland Department of Environment and Resource Management.

Devlin, M., Brodie, J., Wenger, A., da Silva, E., Alvarez-Romero, J. G., Waterhouse, J., et al. (2012). "Extreme weather conditions in the Great Barrier Reef: drivers of change," in Proceedings of the 12th International Coral Reef Symposium, (Cairns).

Dichmont, C. M., Ellis, N., Bustamante, R. H., Deng, R., Tickell, S., Pascual, R., et al. (2013). Evaluating marine spatial closures with conflicting fisheries and conservation objectives. J. Appl. Ecol. 50, 1060-1070. doi: 10.1111/1365-2664. 12110

Diffenbaugh, N. S., and Scherer, M. (2011). Observational and model evidence of global emergence of permanent, unprecedented heat in the 20th and 21st centuries. Clim. Change 107, 615-624. doi: 10.1007/s10584-011-0112-y

Duke, N. C., Kovacs, J. M., Griffiths, A. D., Preece, L., Hill, D. J., Van Oosterzee, P., et al. (2017). Large-scale dieback of mangroves in Australia's Gulf of Carpentaria: a severe ecosystem response, coincidental with an unusually extreme weather event. Mar. Freshw. Res. 68, 1816-1829.

Edgar, G. J., Barrett, N. S., Morton, A. J., and Samson, C. R. (2004). Effects of algal canopy clearance on plant, fish and macroinvertebrate communities on eastern Tasmanian reefs. J. Exp. Mar. Biol. Ecol. 312, 67-87. doi: 10.1016/j.jembe.2004. 06.005

Feng, M., Hendon, H. H., Xie, S. P., Marshall, A. G., Schiller, A., Kosaka, Y., et al. (2015). Decadal increase in Ningaloo Niño since the late 1990s. Geophys. Res. Lett. 42, 104-112.

Feng, M., McPhaden, M. J., Xie, S. P., and Hafner, J. (2013). La Niña forces unprecedented Leeuwin current warming in 2011. Sci. Rep. 3:1277. doi: 10.1038/ srep01277

Fischer, E. M., Beyerle, U., and Knutti, R. (2013). Robust spatially aggregated projections of climate extremes. Nat. Clim. Change 3, 1033-1038. doi: 10.1038/ nclimate 2051

Fisher, R., O’Leary, R. A., Low-Choy, S., Mengersen, K., Knowlton, N., Brainard, R. E., et al. (2015). Species richness on coral reefs and the pursuit of convergent global estimates. Curr. Biol. 25, 500-505. doi: 10.1016/j.cub.2014.12.022

Forrest, R. E., Savina, M., Fulton, E. A., and Pitcher, T. J. (2015). Do marine ecosystem models give consistent policy evaluations? A comparison of Atlantis and Ecosim. Fish. Res. 167, 293-312. doi: 10.1016/j.fishres.2015.03.010

Fraser, M. W., Kendrick, G. A., Statton, J., Hovey, R. K., Zavala-Perez, A., and Walker, D. I. (2014). Extreme climate events lower resilience of foundation seagrass at edge of biogeographical range. J. Ecol. 102, 1528-1536. doi: 10.1111/ 1365-2745.12300

Frieler, K., Meinshausen, M., Golly, A., Mengel, M., Lebek, K., Donner, S. D., et al. (2013). Limiting global warming to $2^{\circ} \mathrm{C}$ is unlikely to save most coral reefs. Nat. Clim. Change 3, 165-170. doi: 10.1038/nclimate1674

Fulton, E. A., Gray, R., Sporcic, M., Scott, R., Little, R., Hepburn, M., et al. (2011). Ningaloo Collaboration Cluster: Adaptive Futures for Ningaloo. Ningaloo Collaboration Cluster Final Report No. 5.3. Hobart, TAS: Ningaloo Collaboration Cluster.

Fulton, E. A., Smith, A. D., Smith, D. C., and Johnson, P. (2014). An integrated approach is needed for ecosystem based fisheries management: insights from ecosystem-level management strategy evaluation. PLoS One 9:e84242. doi: 10. 1371/journal.pone.0084242

Glynn, P. W., Maté, J. L., Baker, A. C., and Calderón, M. O. (2001). Coral bleaching and mortality in Panama and Ecuador during the 1997-1998 El
Niño-Southern Oscillation event: spatial/temporal patterns and comparisons with the 1982-1983 event. Bull. Mar. Sci. 69, 79-109.

Graham, N. A. (2014). Habitat complexity: coral structural loss leads to fisheries declines. Curr. Biol. 24, R359-R361. doi: 10.1016/j.cub.2014.03.069

Grant, P. R., Grant, B. R., Huey, R. B., Johnson, M. T., Knoll, A. H., and Schmitt, J. (2017). Evolution caused by extreme events. Philos. Trans. R. Soc. B 372:20160146.

Gray, R., Fulton, E. A., and Little, L. R. (2013). "Human-ecosystem interaction in large ensemble-model systems," in Empirical Agent-Based Modeling: Challenges and Solutions, eds A. Smajgl and O. Barreteau (Berlin: Springer), 249.

Great Barrier Reef Marine Park Authority (2011). Impacts of Tropical Cyclone Yasi on the Great Barrier Reef: a Report on the Findings of a Rapid Ecological Impact Assessment. Queensland: Great Barrier Reef Marine Park Authority.

Great Barrier Reef Marine Park Authority (2017). Reef Health Update June 292017. Available at: http://www.gbrmpa.gov.au/about-the-reef/reef-health (accessed August 23, 2018).

Grech, A., and Coles, R. G. (2010). An ecosystem-scale predictive model of coastal seagrass distribution. Aquat. Conserv. Mar. Freshw. Ecosyst. 20, 437-444. doi: 10.1002/aqc. 1107

Gribble, N. A. (2003). GBR-prawn: modelling ecosystem impacts of changes in fisheries management of the commercial prawn (shrimp) trawl fishery in the far northern Great Barrier Reef. Fish. Res. 65, 493-506. doi: 10.1016/j.fishres. 2003.09.035

Halpern, B. S., Walbridge, S., Selkoe, K. A., Kappel, C. V., Micheli, F., D’agrosa, C., et al. (2008). A global map of human impact on marine ecosystems. Science 319, 948-952.

Hanington, P., Hunnam, K., and Johnstone, R. (2015). Widespread loss of the seagrass Syringodium isoetifolium after a major flood event in Moreton Bay, Australia: implications for benthic processes. Aquat. Bot. 120, 244-250. doi: 10.1016/j.aquabot.2014.09.002

Harris, R. M. B., Beaumont, L. J., Vance, T. R., Tozer, C. R., Remenyi, T. A., and Letnic, M. (2018). Biological responses to the press and pulse of climate trends and extreme events. Nat. Clim. Change 8:579.

Heron, S. F., Eakin, C. M., Douvere, F., Anderson, K., Day, J. C., and Obura, D. (2017). Impacts of Climate Change on World Heritage Coral Reefs: A First Global Scientific Assessment. Paris: UNESCO World Heritage Centre.

Herring, S. C., Christidis, N., Hoell, A., Kossin, J. P., Schreck, C. J. III, and Stott, P. A. (2018). Explaining extreme events of 2016 from a climate perspective. Bull. Am. Meteorol. Soc. 99, S1-S157.

Herring, S. C., Hoerling, M. P., Peterson, T. C., and Stott, P. A. (2014). Explaining extreme events of 2013 from a climate perspective. Bull. Am. Meteorol. Soc. 95, S1-S104.

Hesse, J., Stanley, J. A., and Jeffs, A. G. (2016). Relative predation risk in two types of habitat for juvenile Australasian spiny lobsters, Jasus edwardsii. Mar. Biol. Res. 12, 895-906. doi: 10.1080/17451000.2016.1236200

Hinojosa, I. A., Green, B. S., Gardner, C., and Jeffs, A. (2014). Settlement and early survival of southern rock lobster, Jasus edwardsii, under climate-driven decline of kelp habitats. ICES J. Mar. Sci. 72(Suppl. 1), i59-i68. doi: 10.1093/icesjms/ fsu199

Hobday, A. J., Alexander, L. V., Perkins, S. E., Smale, D. A., Straub, S. C., Oliver, E. C. J., et al. (2016). A hierarchical approach to defining marine heatwaves. Prog. Oceanogr. 141, 227-238. doi: 10.1016/j.pocean.2015.12.014

Hodgkinson, J. H., Hobday, A. J., and Pinkard, E. A. (2014). Climate adaptation in Australia's resource-extraction industries: ready or not? Reg. Environ. Change 14, 1663-1678. doi: 10.1007/s10113-014-0618-8

Hughes, T. P., and Kerry, J. T. (2017). Back-to-Back Bleaching has now Hit Two-Thirds of the Great Barrier Reef, The Conversation. Available at: http: //theconversation.com/back-to-back-bleaching (accessed July 12, 2019).

Hughes, T. P., Kerry, J. T., Álvarez-Noriega, M., Álvarez-Romero, J. G., Anderson, K. D., Baird, A. H., et al. (2017). Global warming and recurrent mass bleaching of corals. Nature 543, 373-377. doi: 10.1038/nature 21707

Hughes, T. P., Kerry, J. T., Baird, A. H., Connolly, S. R., Chase, T. J., Dietzel, A., et al. (2019). Global warming impairs stock-recruitment dynamics of corals. Nature 568, 387-390. doi: 10.1038/s41586-019-1081-y

Hughes, T. P., Kerry, J. T., Baird, A. H., Connolly, S. R., Dietzel, A., Eakin, C. M., et al. (2018). Global warming transforms coral reef assemblages. Nature 556, 492-496. doi: 10.1038/s41586-018-0041-2 
IPCC (2012). "Managing the risks of extreme events and disasters to advance climate change adaptation," in A Special Report of Working Groups I and II of the Intergovernmental Panel on Climate Change, eds C. B. Field, V. Barros, T. F. Stocker, D. Qin, D. J. Dokken, K. L. Ebi, et al. (Cambridge: Cambridge University Press), 582.

Johnson, C. R., Banks, S. C., Barrett, N. S., Cazassus, F., Dunstan, P. K., Edgar, G. J., et al. (2011). Climate change cascades: shifts in oceanography, species' ranges and subtidal marine community dynamics in eastern Tasmania. J. Exp. Mar. Biol. Ecol. 400, 17-32. doi: 10.1016/j.jembe.2011.02.032

Kennedy, E. V., Ordoñez, A., and Diaz-Pulido, G. (2018). Coral bleaching in the southern inshore Great Barrier Reef: a case study from the Keppel Islands. Mar. Freshw. Res. 69, 191-197.

Lafratta, A., Fromont, J., Speare, P., and Schönberg, C. H. L. (2017). Coral bleaching in turbid waters of north-western Australia. Mar. Freshw. Res. 68, 65-75.

Lenoir, J., and Svenning, J. C. (2015). Climate-related range shifts-a global multidimensional synthesis and new research directions. Ecography 38, 15-28. doi: $10.1111 /$ ecog.00967

Lin, Q., and Mendelssohn, I. A. (2012). Impacts and recovery of the Deepwater Horizon oil spill on vegetation structure and function of coastal salt marshes in the northern Gulf of Mexico. Environ. Sci. Technol. 46, 3737-3743. doi: $10.1021 / \mathrm{es} 203552 \mathrm{p}$

Ling, S. D. (2008). Range expansion of a habitat-modifying species leads to loss of taxonomic diversity: a new and impoverished reef state. Oecologia 156, 883-894. doi: 10.1007/s00442-008-1043-9

Liu, Y., Cobb, K. M., Song, H., Li, Q., Li, C. Y., Nakatsuka, T., et al. (2017). Recent enhancement of central Pacific El Niño variability relative to last eight centuries. Nat. Commun. 8:15386.

Longstaff, B. J., and Dennison, W. C. (1999). Seagrass survival during pulsed turbidity events: the effects of light deprivation on the seagrasses Halodule pinifolia and Halophila ovalis. Aquat. Bot. 65, 105-121. doi: 10.1016/s03043770(99)00035-2

Lovelock, C. E., Feller, I. C., Reef, R., Hickey, S., and Ball, M. C. (2017). Mangrove dieback during fluctuating sea levels. Sci. Rep. 7:1680. doi: 10.1038/s41598-01701927-6

Lozano-Montes, H. M., Loneragan, N. R., Babcock, R. C., and Jackson, K. (2011). Using trophic flows and ecosystem structure to model the effects of fishing in the Jurien Bay Marine Park, temperate Western Australia. Mar. Freshw. Res. 62, $421-431$.

Lucas, R., Finlayson, C., Bartolo, R., Rogers, K., Mitchell, A., Woodroffe, C., et al. (2017). Historical perspectives on the Mangroves of Kakadu National Park. Mar. Freshw. Res. Mar. Freshw. Res. 69, 1047-1063.

Mann, M. E., Rahmstorf, S., Kornhuber, K., Steinman, B. A., Miller, S. K., and Coumou, D. (2017). Corrigendum: influence of anthropogenic climate change on planetary wave resonance and extreme weather events. Sci. Rep. 7:46822. doi: $10.1038 /$ srep 46822

Martínez, B., Radford, B., Thomsen, M. S., Connell, S. D., Carreño, F., Bradshaw, C. J., et al. (2018). Distribution models predict large contractions of habitatforming seaweeds in response to ocean warming. Divers. Distrib. 24, 1350-1366. doi: 10.1111/ddi.12767

McInnes, K., Abbs, D., Bhend, J., Chiew, F., Church, J., Ekström, M., et al. (2015). in Wet Tropics Cluster Report, Climate Change in Australia Projections for Australia's Natural Resource Management Regions: Cluster Reports, eds M. Ekström, et al. (Melbourne: CSIRO and Bureau of Meteorology). doi: 10.1111/ ddi. 12767

McKenna, S. A., and Rasheed, M. A. (2013). Port of Abbot Point Long-Term Seagrass Monitoring: Annual Report 2011-2012. Cairns: Centre for Tropical Water and Aquatic Ecosystem Research.

McKenzie, L. J., Collier, C., and Waycott, M. (2012). Reef Resource Marine Monitoring Program - Inshore seagrass. Annual Report for the sampling period 1st July 2010 - 31st May 2011. Cairns: Fisheries Queensland.

McKenzie, L. J., Collier, C., and Waycott, M. (2014). Reef Rescue Marine Monitoring Program: Inshore seagrass, Annual Report for the Sampling Period 1st July 2011 31st May 2012. Cairns: Fisheries Queensland.

Meager, J. J., and Limpus, C. (2014). Mortality of inshore marine mammals in eastern Australia is predicted by freshwater discharge and air temperature. PLoS One 9:e94849. doi: 10.1371/journal.pone.0094849

Mislan, K. A. S., and Wethey, D. S. (2015). A biophysical basis for patchy mortality during heat waves. Ecology 96, 902-907. doi: 10.1890/14-1219.1
Moore, J. A., Bellchambers, L. M., Depczynski, M. R., Evans, R. D., Evans, S. N., Field, S. N., et al. (2012). Unprecedented mass bleaching and loss of coral across 12 degrees of latitude in Western Australia in 2010-11. PLoS One 7:e51807. doi: 10.1371/journal.pone.0051807

Nagelkerken, I., Blaber, S. J. M., Bouillon, S., Green, P., Haywood, M., Kirton, L. G., et al. (2008). The habitat function of mangroves for terrestrial and marine fauna: a review. Aquat. Bot. 89, 155-185. doi: 10.1016/j.aquabot.2007.12.007

Oliver, E. C., Benthuysen, J. A., Bindoff, N. L., Hobday, A. J., Holbrook, N. J., Mundy, C. N., et al. (2017). The unprecedented 2015/16 Tasman Sea marine heatwave. Nat. Commun. 8:16101. doi: 10.1038/ncomms16101

Oliver, E. C. J., Donat, M. G., Burrows, M. T., Moore, P. J., Smale, D. A., Alexander, L. V., et al. (2018a). Ocean warming brings longer and more frequent marine heatwaves. Nat. Commun. 9:1324. doi: 10.1038/s41467-018-03732-9

Oliver, E. C. J., Perkins-Kirkpatrick, S. E., Holbrook, N. J., and Bindoff, N. L. (2018b). Anthropogenic and natural influences on record 2016 marine heatwaves. Bull. Am. Meteorol. Soc. 99, S44-S48.

Orth, R. J., Carruthers, T. J., Dennison, W. C., Duarte, C. M., Fourqurean, J. W., Heck, K. L., et al. (2006). A global crisis for seagrass ecosystems. AIBS Bull. 56, 987-996.

Paling, E., Kobryn, H., and Humphreys, G. (2008). Assessing the extent of mangrove change caused by cyclone vance in the eastern Exmouth Gulf, northwestern Australia. Estuar. Coast. Shelf Sci. 77, 603-613. doi: 10.1016/j. ecss.2007.10.019

Parida, A. K., and Jha, B. (2010). Salt tolerance mechanisms in mangroves: a review. Trees 24, 199-217. doi: 10.1007/s00468-010-0417-x

Perry, C. T., and Morgan, K. M. (2017a). Bleaching drives collapse in reef carbonate budgets and reef growth potential on southern Maldives reefs. Sci. Rep. 7:40581. doi: 10.1038/srep40581

Perry, C. T., and Morgan, K. M. (2017b). Post-bleaching coral community change on southern Maldivian reefs: is there potential for rapid recovery? Coral Reefs 36, 1189-1194. doi: 10.1007/s00338-017-1610-9

Pinsky, M. L., Eikeset, A. M., McCauley, D. J., Payne, J. L., and Sunday, J. M. (2019). Greater vulnerability to warming of marine versus terrestrial ectotherms. Nature 569:108. doi: 10.1038/s41586-019-1132-4

Poloczanska, E. S., Brown, C. J., Sydeman, W. J., Kiessling, W., Schoeman, D. S., Moore, P. J., et al. (2013). Global imprint of climate change on marine life. Nat. Clim. Change 3, 919-925. doi: 10.1038/nclimate1958

Pratchett, M. S., Hoey, A. S., Wilson, S. K., Messmer, V., and Graham, N. A. (2011). Changes in biodiversity and functioning of reef fish assemblages following coral bleaching and coral loss. Diversity 3, 424-452. doi: 10.1111/gcb.14119

Przeslawski, R., Ahyong, S., Byrne, M., Woerheide, G., and Hutchings, P. A. T. (2008). Beyond corals and fish: the effects of climate change on noncoral benthic invertebrates of tropical reefs. Glob. Change Biol. 14, 2773-2795. doi: 10.1111/ j.1365-2486.2008.01693.x

Richardson, L. E., Graham, N. A. J., Pratchett, M. S., Eurich, J. G., and Hoey, A. S. (2018). Mass coral bleaching causes biotic homogenization of reef fish assemblages. Glob. Change Biol. 2018, 1-13. doi: 10.1111/gcb.14119

Ridgway, K. R. (2007). Long-term trend and decadal variability of the southward penetration of the East Australian Current. Geophys. Res. Lett. 34. doi: 10.1029/ 2007GL030393

Ridgway, T., Inostroza, K., Synnot, L., Trapon, M., Twomey, L., and Westera, M. (2016). Temporal patterns of coral cover in the offshore Pilbara, Western Australia. Mar. Biol. 163, 182.

Rochford, D. J. (1984). Effect of the Leeuwin Current upon sea surface temperatures off south-western Australia. Mar. Freshw. Res. 35, 487-489.

Rosenzweig, C., Karoly, D., Vicarelli, M., Neofotis, P., Wu, Q., Casassa, G., et al. (2008). Attributing physical and biological impacts to anthropogenic climate change. Nature 453, 353-357. doi: 10.1038/nature06937

Scheffer, M., Carpenter, S., Foley, J. A., Folke, C., and Walker, B. (2001). Catastrophic shifts in ecosystems. Nature 413:591. doi: 10.1038/35098000

Schindler, D. E., and Hilborn, R. (2015). Prediction, precaution, and policy under global change. Science 347, 953-954. doi: 10.1126/science.1261824

Smale, D. A., and Vance, T. (2016). Climate-driven shifts in species' distributions may exacerbate the impacts of storm disturbances on North-east Atlantic kelp forests. Mar. Freshw. Res. 67, 65-74.

Smale, D. A., and Wernberg, T. (2013). Extreme climatic event drives range contraction of a habitat-forming species. Philos. Trans. R. Soc. Lond. Ser. B 280:20122829. doi: 10.1098/rspb.2012.2829 
Smale, D. A., Wernberg, T., Oliver, E. C., Thomsen, M., Harvey, B. P., Straub, S. C., et al. (2019). Marine heatwaves threaten global biodiversity and the provision of ecosystem services. Nat. Clim. Change 9, 306-312. doi: 10.1038/s41558-0190412-1

Smith, D. J., Suggett, D. J., and Baker, N. R. (2005). Is photoinhibition of zooxanthellae photosynthesis the primary cause of thermal bleaching in corals? Glob. Change Biol. 11, 1-11. doi: 10.1111/j.1529-8817.2003.00895.x

Smith, M. D. (2011). An ecological perspective on extreme climatic events: a synthetic definition and framework to guide future research. J. Ecol. 99, 656663. doi: 10.1111/j.1365-2745.2011.01798.x

Sommer, B., Beger, M., Harrison, P. L., Babcock, R. C., and Pandolfi, J. M. (2018). Differential response to abiotic stress controls species distributions at biogeographic transition zones. Ecography 41, 478-490. doi: 10.1111/ecog. 02986

Spalding, M., Burke, L., Wood, S. A., Ashpole, J., Hutchison, J., and Zu Ermgassen, P. (2017). Mapping the global value and distribution of coral reef tourism. Mar. Policy 82, 104-113. doi: 10.1016/j.marpol.2017.05.014

Speed, C. W., Babcock, R. C., Bancroft, K. P., Beckley, L. E., Bellchambers, L. M., Depczynski, M., et al. (2013). Dynamic stability of coral reefs on the west Australian coast. PLoS One 8:e69863. doi: 10.1371/journal.pone.0069863

Steneck, R. S., Graham, M. H., Bourque, B. J., Corbett, D., Erlandson, J. M., Estes, J. A., et al. (2002). Kelp forest ecosystems: biodiversity, stability, resilience and future. Environ. Conserv. 29, 436-459. doi: 10.1017/s0376892902000322

Steneck, R. S., Vavrinec, J., and Leland, A. V. (2004). Accelerating trophic-level dysfunction in kelp forest ecosystems of the western North Atlantic. Ecosystems 7, 323-332.

Stocker, T. (2014). Climate change 2013: the physical science basis: Working Group I contribution to the Fifth assessment report of the Intergovernmental Panel on Climate Change. Cambridge: Cambridge University Press.

Stuart-Smith, R. D., Brown, C. J., Ceccarelli, D. M., and Edgar, G. J. (2018). Ecosystem restructuring along the Great Barrier Reef following mass coral bleaching. Nature 560:92. doi: 10.1038/s41586-018-0359-9

Sunday, J. M., Bates, A. E., and Dulvy, N. K. (2011). Global analysis of thermal tolerance and latitude in ectotherms. Proc. R. Soc. Lond. B Biol. Sci. 278, 1823-1830. doi: 10.1098/rspb.2010.1295

Sunday, J. M., Bates, A. E., and Dulvy, N. K. (2012). Thermal tolerance and the global redistribution of animals. Nat. Clim. Change 2:686. doi: 10.1038/ nclimate 1539

Thomson, J. A., Burkholder, D. A., Heithaus, M. R., Fourqurean, J. W., Fraser, M. W., Statton, J., et al. (2015). Extreme temperatures, foundation species, and abrupt ecosystem change: an example from an iconic seagrass ecosystem. Glob. Change Biol. 21, 1463-1474. doi: 10.1111/gcb.12694

Travis, W. R. (2014). Weather and climate extremes - pacemakers of adaptation? Weather Clim. Extrem. 5-6, 29-39. doi: 10.1016/j.wace.2014.08.001

Underwood, A. J. (1989). The analysis of stress in natural populations. Biol. J. Linn. Soc. 37, 51-78. doi: 10.1111/j.1095-8312.1989.tb02005.x

van de Pol, M., Jenouvrier, S., Cornelissen, J. H., and Visser, M. E. (2017). Behavioural, ecological and evolutionary responses to extreme climatic events: challenges and directions. Philos. Trans. R. Soc. Lond. Ser. B 372:20160134. doi: $10.1098 /$ rstb.2016.0134

Vergés, A., Doropoulos, C., Malcolm, H. A., Skye, M., Garcia-Pizá, M., Marzinelli, E. M., et al. (2016). Long-term empirical evidence of ocean warming leading to tropicalization of fish communities, increased herbivory, and loss of kelp. Proc. Natl. Acad. Sci. U.S.A. 113, 13791-13796. doi: 10.1073/pnas.16107 25113

Wahl, M., Molis, M., Hobday, A. J., Dudgeon, S., Neumann, R., Steinberg, P., et al. (2015). The responses of brown macroalgae to environmental change from local to global scales: direct versus ecologically mediated effects. Perspect. Phycol. 2, 11-29. doi: 10.1127/pip/2015/0019

Walker, D. I., and Cambridge, M. L. (1995). An experimental assessment of the temperature responses of two sympatric seagrasses, Amphibolis antarctica and Amphibolis griffithii, in relation to their biogeography. Hydrobiologia 302, 63-70. doi: 10.1007/bf00006399

Walsh, K. J., McBride, J. L., Klotzbach, P. J., Balachandran, S., Camargo, S. J., Holland, G., et al. (2016). Tropical cyclones and climate change. Wiley Interdiscip. Rev. Clim. Change 7, 65-89.

Walther, G. R. (2010). Community and ecosystem responses to recent climate change. Philos. Trans. R. Soc. Lond. B Biol. Sci. 365, 2019-2024. doi: 10.1098/ rstb.2010.0021

Watson, R. A., Nowara, G. B., Tracey, S. R., Fulton, E. A., Bulman, C. M., Edgar, G. J., et al. (2013). Ecosystem model of Tasmanian waters explores impacts of climate-change induced changes in primary productivity. Ecol. Modell. 264, 115-129. doi: 10.1016/j.ecolmodel.2012.05.008

Waycott, M., Duarte, C. M., Carruthers, T. J., Orth, R. J., Dennison, W. C., Olyarnik, S., et al. (2009). Accelerating loss of seagrasses across the globe threatens coastal ecosystems. Proc. Natl. Acad. Sci. U.S.A. 106, 12377-12381. doi: 10.1073/pnas.0905620106

Wernberg, T., Bennett, S., Babcock, R. C., de Bettignies, T., Cure, K., Depczynski, M., et al. (2016a). Climate-driven regime shift of a temperate marine ecosystem. Science 353, 169-172. doi: 10.1126/science.aad8745

Wernberg, T., de Bettignies, T., Joy, B. A., and Finnegan, P. M. (2016b). Physiological responses of habitat-forming seaweeds to increasing temperatures. Limnol. Oceanogr. 61, 2180-2190. doi: 10.1371/journal.pone. 0143031

Wernberg, T., Smale, D. A., Tuya, F., Thomsen, M. S., Langlois, T. J., De Bettignies, T., et al. (2013). An extreme climatic event alters marine ecosystem structure in a global biodiversity hotspot. Nat Clim. Change 3, 78-82. doi: 10.1038/ nclimate 1627

Wernberg, T., Thomsen, M. S., Tuya, F., Kendrick, G. A., Staehr, P. A., and Toohey, B. D. (2010). Decreasing resilience of kelp beds along a latitudinal temperature gradient: potential implications for a warmer future. Ecol. Lett. 13, 685-694. doi: 10.1111/j.1461-0248.2010.01466.x

Wetz, M. S., and Yoskowictz, D. W. (2013). An 'extreme' future for estuaries? Effects of extreme climatic events on estuarine water quality and ecology. Mar. Pollut. Bull. 69, 7-18. doi: 10.1016/j.marpolbul.2013.01.020

Widlansky, M. J., Timmermann, A., and Cai, W. (2015). Future extreme sea level seesaws in the tropical Pacific. Sci. Adv. 1:e1500560. doi: 10.1126/sciadv. 1500560

Wilkinson, C. C. (2004). Status of Coral Reefs of the World: 2004. Townsville: Australian Institute of Marine Science (AIMS).

Xu, J., Lowe, R. J., Ivey, G. N., Pattiaratchi, C., Jones, N. L., and Brinkman, R. (2013). Dynamics of the summer shelf circulation and transient upwelling off Ningaloo Reef, Western Australia. J. Geophys. Res. Oceans 118, 1099-1125. doi: 10.1002/jgrc.20098

Zhang, N., Feng, M., Hendon, H. H., Hobday, A. J., and Zinke, J. (2017). Opposite polarities of ENSO drive distinct patterns of coral bleaching potentials in the southeast Indian Ocean. Sci. Rep. 7, 2443. doi: 10.1038/s41598-017-02688-y

Zhang, X., Wan, H., Zwiers, F. W., Hegerl, G. C., and Min, S. K. (2013). Attributing intensification of precipitation extremes to human influence. Geophys. Res. Lett. 40, 5252-5257. doi: 10.1002/grl.51010

Conflict of Interest Statement: The authors declare that the research was conducted in the absence of any commercial or financial relationships that could be construed as a potential conflict of interest.

Copyright (C 2019 Babcock, Bustamante, Fulton, Fulton, Haywood, Hobday, Kenyon, Matear, Plagányi, Richardson and Vanderklift. This is an open-access article distributed under the terms of the Creative Commons Attribution License (CC BY). The use, distribution or reproduction in other forums is permitted, provided the original author(s) and the copyright owner(s) are credited and that the original publication in this journal is cited, in accordance with accepted academic practice. No use, distribution or reproduction is permitted which does not comply with these terms. 